\title{
INSIDER/OUTSIDER PERSPECTIVE IN RELIGIONS AND ISLAMIC STUDIES
}

\author{
Oleh : Untung Khoiruddin *
}

\begin{abstract}
Abstrak
Kim Knott memberikan beberapa kontribusi terhadap pengetahuan (knowledge) antara lain: Pertama, memberikan sumbangan mengenai pemetaan insider dan outsider dalam studi agama. Kedua, memberikan sumbangan pemikiran yang berkaitan dengan pendekatan dalam penelitian studi agama. Dengan pendekatan spasial Kim Knott berusaha membedah masalah seputar agama. Namun, apabila kita kaji kembali tawaran Kim Knott ini tidak hanya bisa untuk mengkaji studi agama saja, lebih dari itu, bisa masuk pada wilayah kelimuan lain.

Kim Knott membagi konsepsi peran pemberdayaan interkoneksi sosial keagamaan dalam empat macam, yaitu : partisipan murni (Complete Participant), peneliti sebagai partisipan (Observer as Participant), partisipan sebagai peneliti (Participant as Observer) dan peneliti murni (Complete Observer).

Insider/outsider dalam studi agama, yaitu: belief, habit of mind, doubt, Inquiry (penelitian), dan the logic of theory.
\end{abstract}

Key Words: Insider, Outsider dan Islamic Studies

\section{PENDAHULUAN}

Bahwa menurut kajian Kim Knott ada hal-hal yang baru tentang studi agama, karena ini muncul adanya problem yang dialami oleh para aktifis kampus di beberapa perguruan tinggi/universitas - baik di Barat maupun di Timur tentang adanya satgnasi pendekatan studi agama. Oleh karena itu relevansinya adalah bagaimana pengkajian Islam dari outsider itu benar-benar obyektif dan dapat dipertanggungjawabkan validitas data dari sudut pandang insider. Akhirnya Kim Knott memberikan tawaran baru tentang pendekatan spasial. Dan juga terjadinya stagnasi metodologis dan pendekatan di kalangan mahasiswa dalam melakukan kajian eksploratif tentang agama. Dalam kajian ini, Knott mencoba meretas dan mengeliminir

${ }^{*}$ STAIN Kediri

Volume 24 Nomor 2 September 2013 
anasir subjektivitas, dengan mengurai dua persoalan mendasar antara perspektif emik yang muncul dari kajian orang dalam (insider), dan perspektif etik yang muncul dari orang luar (outsider). Oleh karena itu, yang menjadi persoalan adalah apakah para pengkaji Islam dari outsider benar-benar objektif, dapat dipertanggungjawabkan, dan memiliki validitas ilmiah dilihat dari optik insider. Itu sebabnya, Kim Knott mencoba meletakkan kedua kerangka tersebut dalam bingkai rapprochment. Pendekatan ini, merupakan upaya solutif inter subjektif guna memposisikan peneliti pada margin of appreciation sebagai tapal batas (border line) antara insideroutsider..

Bahwa kalau kita melihat wacana antara barat dan timur tidak akan pernah selesai untuk dibahas. Islam dan Barat rupanya telah memiliki muataan konseptual ideologis, sebagaimana juga istilah orientalisme yang memiliki konotasi negatif karena dinilai memiliki agenda tersembunyi dari para intelektual Barat non Muslim yang sengaja mempelajari Islam dan dunia Islam disertai niat yang tidak tulus atau bahkan sengaja mencari kelemahan Islam dalam rangka penaklukan. Jika dicermati, secara intelektual akademis barangkali perhatian sarjana-sarjana Muslim terhadap Barat (tradisi Kristiani) tidak seimbang apabila dibandingkan dengan perhatian intelektual Barat terhadap Timur (Islam). Posisi yang tidak seimbang ini pada akhirnya memunculkan setereotip-setereotip yang meuncul dari ketidaktahuan dan sikap penuh dengan prasangka negatif tentang Islam. ${ }^{1}$

Dalam sistem keagamaan kontemporer dinyatakan, bahwa agama mempunyai banyak sisi. Agama tidak hanya terkait dengan persoalan kredo, keyakinan, worldview, ketuhanan dan lainnya, namun meluas spektrumnya pada pelbagai aspek historis kultural. ${ }^{2}$ Yang terdapat dua persoalan yang menjadi kegelisahan akademik Kim Knott, berdasar pada persoalan di

\footnotetext{
1. Hasan Hanafi, Oksidentalisme: Sikap Kita Terhadap Tradisi Barat, terj. (Jakarta: Paramadina, 2000), hlm. XV

2. M. Amin Abdullah, "Relevansi Studi Agama-Agama dalam Milenium Ketiga ” dalam Amin Abdullah dkk., Mencari Islam (Studi Islam dengan Berbagai Pendekatan), (Yogyakarta: Tiara Wacana, 2000), hlm. 12
} 
atas sehingga ia membuat pemetaan pendekatan studi agama. Pertama, betapa sulitnya membuat garis demokrasi yang jelas antara wilayah agama dan yang tidak. Kedua, adanya persoalan yang sangat rumit ketika ada yang memahami agama, antara ia sebagai tradisi (tradition) dan sebagai keimanan (faith).

\section{Permasalahan ( Kegelisahan Akademik ).}

Kegelisahan akademik Kim Knott diawali dengan persoalan yang dialami oleh mahasiswa yang menempuh studi agama adalah pengembangan pemahaman agama. Dalam studi agama mereka memahami riwayat hidup orang-orang yang beragama dan posisinya pada saat ini adalah sebagai outsider. Akan tetapi mahasiswa juga bisa menjadi insider dalam kasus yang lain. Yaitu, ketika mereka memiliki pengalaman subjektif tersendiri mengenai agama yang mereka gambarkan dan yang mereka tulis. Kemudian muncul pertanyaan selanjutnya, dapatkah kita memahami persoalan mendalam tentang pemahaman keagamaan seseorang ?. Apa bedanya antara pendapat insider dan outsider tentang agama? Apakah ada jurang pemisah antara orang yang menulis riwayat hidup (pengalaman keagamaan) dengan mereka yang membaca riwayat hidup (pengalaman agama orang lain) ?.

Melihat hal diatas berarti ada beberapa kegelisahan akademik Kim Knott yang dapat dipetakan. Pertama, sangat sulit membuat batas antara wilayah agama dan yang bukan. Kedua, adanya kesulitan antara memahami agama sebagai tradisi dan keimanan. Ketiga, terjadinya stagnasi metodologis dan pendekatan dikalangan akademisi mengenai agama. Mereka dituntut se obyektif mungkin dalam memahami agama disisi lain, mereka harus meletakkan agama dalam nilai transendensi yang harus di junjung tinggi. Tapi yang menjadi pokok permasalahan utama adalah objektifitas, Inilah kegelisahan akademik Kim Knott.

\section{Biografi Intelektual}

Kim Knott merupakan sosok peneliti yang memfokuskan dirinya pada pengembangan metodologi spasial dalam studi agama, guna mencari keterlibatan sirkuler antar agama, baik sosial, budaya, politik, ekonomi dan lainnya. Dalam The 
Location of Religion: A Spatial Analysis, ${ }^{3}$ ia menyatakan bahwa penerapan teori sosio-spasial dalam studi agama, mempunyai korelasi positif dalam tataran implementasi ajaran agama. Penelitian lain difokuskan pada lokus agama dan nilai-nilai universal dalam lanskap sosio-kultural masyarakat dan hubungannya dengan fenomenologi agama. Bersama Thomas A. Tweed, ia bekerja pada sebuah perpustakaan induk untuk geografi agama. Dan, berbasis di University of Leeds, Kim Knott adalah Direktur Riset, Seni dan Humaniora pada program Dewan Diaspora, Migrasi dan Identitas Agama. Ia juga coeditor (bersama Sean McLoughlin) dalam sebuah jurnal Diaspora. Di tingkat regional, Knott duduk sebagai Sekretaris Jenderal Asosiasi Eropa untuk Studi Agama. Ia juga sebagai dosen senior pada Studi Agama di University of Leeds, Inggris. Karena posisi inilah, membawanya menjadi peneliti garda depan tentang agama, sehingga mengantarkannya sebagai penulis produktif pada sejumlah jurnal tentang gerakan-gerakan agama kontemporer di London. Sebagai Profesor Studi Agama dan Direktur Komunitas Antar Agama, Knott menulis tentang agama di Inggris, yang meliputi identitas agama-agama modern, dan isu-isu metodologis tentang studi agama. Kegiatan akademiknya termasuk membantu mahasiswa menjadi peneliti yang kompeten dengan mengangkat isu-isu agama yang lebih luas. Saat ini, ia memfokuskan penelitiannya pada lokasi agama di dua organisasi publik; institusi universitas dan kelompok masyarakat. Dalam penelitiannya, Knott banyak mengadopsi preposisi dan preskripsi yang menggunakan pendekatan teoretis dan induktif berdasar pada budaya lokal. Titik awal dalam mengembangkan pendekatan spasial tersebut adalah Theories of Place yang dikembangkan oleh Heidegger, Edward Casey dan Christopher Tilley. Sebagai seorang feminis dan kritikus post-modern, bagaimanapun juga segera mengantarkannya untuk mempertanyakan wacana yang membuatnya tertarik untuk

3. Kim Knott, The Location of Religion, a Spatial Analysis, (UK London: Equinox Publishing, 2005), First Edition, hlm. 57

4. Sean McLoughlin, Migration, Diaspora and Transnationalism: Transformations of Religion and Culture in a Globalising Age dalam The Routledge Companion to the Study of Religion, Edited by John R. Hinnells (London: Routledge Taylor and Fancis Group, 2005), hlm. 527 
menekuni kajian keagamaan dengan pendekatan geografis dan studi agama-agama. Realitas di atas merupakan pendekatan awal yang diidentifikasi oleh Kim Knott untuk dapat diterapkan pada lokus agama. Pada bagian berikutnya, ia merujuk ke pelbagai sumber dalam studi agama, sebelum menunjukkan bagaimana metode spasial dapat diterapkan sehingga merefleksikan kekuatan dan kelemahannya secara konkret. Menurut Knott, agama harus bekerja dalam parameter ini, karena ia dibentuk berdasarkan titik awal dengan pendekatan spasial. Selanjutnya, ia terus mencoba untuk menemukan konsep agama dalam prosedur yang terukur, simultan dan holistik.

\section{Posisi Insider-Outsider dalam Studi Agama}

Kim Knott menyatakan, bahwa pengalaman keagamaan yang ada dalam diri insider ditampilkan kemudian direspon oleh outsider, dengan mempertimbangkan batas-batas objektivitas dan subjektivitas, yang terpancar dalam pengalaman keagamaan, yang didasari oleh sikap empati dan analisis kritis. Pada titik ini, insider-outsider saling berbagi keseimbangan perspektif dalam sejarah studi agama. Lain halnya dengan Darshan Singh, yang menegaskan bahwa upaya peneliti Barat untuk menafsirkan dan memahami agama sebagai outsider, memandang bahwa konsep dan ajaran agama tidak mudah diakses oleh orang luar atau nonpemeluknya. Makna substansi dari agama terungkap hanya melalui partisipasi secara intensif, dengan mengikuti ajaran pengamalan keagamaannya. Jauh sebelumnya, Max Müller (1873) telah mempertegas bahwa, sebagai objek studi, agama harus ditampilkan secara proporsional, meski ia juga harus dikritisi. Dua puluh tahun kemudian, Cornelius Tiele menekankan kepada para ilmuwan untuk melakukan penelitian dengan mengedepankan objektivitas tanpa menjadi skeptis, melalui studi dan investigasi yang tidak memihak. ${ }^{5}$ Ia juga membedakan antara subjektivitas keagamaan pribadi individu dan objektivitas cara pandang terhadap agama orang lain. Selanjutnya, pelbagai isu seputar studi agama diberi penguatan

5 . Shiddiqi, Nourouzzaman, "Sejarah: Pisau Bedah Ilmu Keislaman" dalam Taufik Abdullah (Ed.), Metodologi Penelitian Agama: Sebuah Pengantar, (Yogyakarta: Tiara Wacana, 1991), hlm. 58 
metodologis, terutama yang berkaitan dengan fenomenologi agama, sebagaimana yang dilakukan oleh Kristensen, Van der Leeuw dan Rudolf Otto di Jerman, kemudian Mircea Eliade dan Wilfred Cantwell Smith di Amerika serta Ninian Smart di Inggris. Mereka menyatakan, bahwa semua agama sebagai fenomena yang unik yang dapat dilihat dari pelbagai sisi (multi faces), otonom dan tak ada bandingannya, namun mampu memberikan pemahaman secara empatik. Tujuan yang mendasari pendekatan fenomenologis adalah untuk mengerti dengan penuh empati berdasarkan pada pengalaman insider, di samping itu kemampuan menahan diri dari penilaian negatif yang muncul dari outsider.

Tak sebatas itu, dua pendekatan yang agak berbeda untuk mempelajari agama telah muncul di Barat dalam beberapa dekade terakhir. Salah satunya adalah scientific method. ${ }^{6}$ Bercampurnya antara "agama" dan "sosio-historis kultural" atau antara yang sakral dan yang profan tidak mudah lagi dibedakan. Jika dalam wilayah keilmuan biasa para ilmuwan masih bisa membuat distingsi antara pure science yang bersifat inklusif terbuka dan applied science yang bersifat eksklusif tertutup lewat telaah filsafat keilmuan kontemporer. Maka, dalam wilayah keilmuan agama, sungguh terasa kesulitan untuk membuat titik pemisah antara keduanya. ${ }^{7}$ Memang, sebagaimana dinyatakan oleh Arkoun, unsur sakralitas (taqdi $>S$ al-afka $>r$ al-diniyyah) yang termuat dalam agama menambah rumitnya persoalan. Dalam hal ini, sering didapati, bahwa wilayah perbincangan keagamaan yang semula bersifat profan, menjadi disakralkan. Berbeda dengan Kim Knott, Charles S. Pierce mengajukan konstruksi pemikiran sebagai basis studi agama: Pertama, belief, yang berupa tatanan sosial yang dipegang secara absolut, dan dipadu oleh tatanan kekuatan moral. Kedua, habit of mind, tradisi yang turun temurun dan telah mengkristal menjadi kebiasaan dalam pelbagai aspek

\footnotetext{
6 . Josef Van Ess, The Logical Structure of Islamic Theology, dalam An Anthology of Islamic Studies, edited by Issa J. Boullata, (Canada: McGill Indonesia IAIN Development Project, 1992), hlm. 24

7. Milton K. Munitz, Contemporary Analytic Philosophy, (New York: Macmillan Publishing Co Inc, 1976), hlm. 403.
} 
kehidupan. Ketiga, doubt mempertanyakan tentang apa yang selama ini dianggap menjadi mainstream pemikiran dan pengejawantahan. Dan, untuk memperoleh keyakinan - menurut C. S. Pierce - seorang peneliti, harus melakukan empat tahapan pertimbangan guna mengurai doubt menjadi potensi positif argumentatif, yakni tenasitas, otoritas, apriori dan investigasi. Keempat, Inquiry (penelitian), namun ia menegaskan bahwa yang dicari adalah meaning (nilai) bukan truth (kebenaran), yang merupakan teori pemaknaan pragmatis namun operatif. Kelima, the logic of theory, sebagai landasan aplikasi kajian. Russell McCutcheon mencoba memberi penguatan guna mengkategorisasikan tanggapan insider ke outsider dalam tiga dimensi; (1) otonomi pengalaman religius, yang terkait dengan pendekatan fenomenologi, (2) reduksionisme, yang dicontohkan oleh komunitas akademisi yang mengambil suatu sikap ilmiah, (3) netralitas dan metode agnostisisme, seperti yang diadopsi oleh Ninian Smart yang mengandalkan ikon outsider dengan mengidentifikasi kebenaran dari perspektif orang lain. Pendekatan yang ditawarkannya ini, menyiratkan pergeseran dari ranah teologi ke filsafat.

Pengalaman religius sebagian besar ada dalam bentuk kognitif eksploratif. Gagasan, konsep, dan kepercayaan merupakan pernyataan formal yang membuat dunia agama yang bersifat pribadi tersebut dapat disampaikan kepada orang lain. ${ }^{8}$ Bahkan, pengalaman mistik yang mungkin sepenuhnya diuraikan dengan bahasa, simbol dan pengalaman empiris dapat dipahami dan ditransformasikan kepada pihak lain.

Sedangkan reduksionisme merupakan aliran yang memandang bahwa sistem kompleks di alam ini dapat direduksi menjadi sistem-sistem yang lebih sederhana atau malahan menjadi sistem paling fundamental. Ide ini pertama kali diperkenalkan oleh Descartes di awal abad ke 17 dan telah menjadi bagian integral dari prinsip pengembangan sains selama hampir empat abad. Pada perkembangannya, reduksionisme diaplikasikan dalam studi agama, ketika banyak yang

8. Brian Morris, Antropologi Agama, Kritik Teori-teori Agama Kontemporer (terjemahan Imam Khoiri), (Yogyakarya: Ak Group, 2003), Cet. I, hlm. 271 
mengasumsikan bahwa reduksionisme sebagai upaya 'simplifikasi' atau lebih tepatnya membuka diri dari keragaman agama dengan empati dan simpati. Dalam wilayah studi agama, usaha yang ditempuh dengan pendekatan sosial ialah memahami agama secara objektif dan signifikansinya dalam kehidupan masyarakat. Tujuan dari pendekatan ini guna menemukan aspek empirik keberagamaan berdasarkan keyakinan, bahwa dengan membongkar sisi empirik dari agama itu, akan membawa seseorang kepada agama yang lebih sesuai dengan realitasnya. Dan itu menurut Kim Knott, sebagaimana dikutip dari Charles J. Adams, diperlukan pendekatan fenomenologi, yakni metode untuk memahami agama seseorang dalam mengkaji pilihan dan komitmen mereka secara netral sebagai persiapan untuk melakukan rekonstruksi pengalaman orang lain.

Pada tahun 1954 oleh ahli bahasa Kenneth L. Pike, ${ }^{10}$ yang berpendapat bahwa alat yang dikembangkan untuk menggambarkan perilaku linguistik dapat disesuaikan dengan uraian tentang perilaku sosial manusia. Emik dan etik berasal dari istilah linguistik fonemik dan fonetik, yang pada gilirannya berasal dari bahasa Yunani. Kenneth L. Pike mengusulkan dikotomi emik-etik dalam antropologi sebagai cara mengurai seputar isu-isu filosofis tentang objektivitas. Kenneth L. Pike, mengurai dua persoalan mendasar antara perspektif emik yang muncul dari kajian kepribadian seseorang dari insider, sedangkan perspektif etik muncul dari outsider. Ia menyatakan, "The etic perspective is the observer's subsequent attempt to take the descriptive information they have already gathered and to organize, systematize, compare - in a word redescribe - that information in terms of a system of their own making....",11

9. Adams, Charles J., "Islamic Religious Tradition" dalam Leonard Binder (Ed.) The Study of The Middle East : Research and Scholarship in the Humanities and the Social Science, (Canada: John Wiley and Sonc, Inc, 1976), hlm. 8

10 . Kenneth L. Pike, Etic and Emic Standpoints for the Descpription of Behavior dalam Russell T. McCutchceon, The Insider-Outsider Problem in the Study of Religion, (London: Cassel, 1999), First Edition, hlm. 29.

11. Russell T. McCutchceon, The Insider-Outsider Problem in the Study of Religion, (London: Cassel, 1999), First Edition, p. 17. 
Antropolog Ward Goodenough dan Marvin Harris dengan konotasi yang sedikit berbeda dari yang digunakan oleh Kenneth L. Pike. Goodenough lebih tertarik untuk memahami makna budaya spesifik dari aspek praksis dan keyakinan tertentu. Sedangkan Harris lebih memberi aksentuasi pada perilaku manusia. Sedangkan, Karen Mc Carthy Brown lebih senang menggunakan istilah "the other" untuk penyebutan 'outsider'. berpendapat bahwa budaya insider-outsider sama-sama mampu memposisikan emik dan etik dalam budaya mereka. Namun demikian, secara umum beberapa peneliti menggunakan "etik" untuk merujuk pada tataran objektif atau luar, dan "emik" untuk merujuk pada tataran subjektif, dari dalam komunitas keberagamaan. Secara singkat, emik mengacu pada pandangan warga masyarakat yang dikaji, sedangkan etik mengacu pada pandangan si peneliti. Konstruksi emik adalah deskripsi dan analisis yang dilakukan dalam konteks skema dan kategori konseptual yang dianggap bermakna bagi partisipan dalam suatu kejadian atau situasi yang dideskripsikan dan dianalisis. Sedangkan, konstruksi etik merupakan deskripsi dan analisis yang dilakukan untuk konteks skema dan kategori konseptual yang dianggap bermakna oleh pihak luar sebagai komunitas ilmiah yang kritis. Robert Lawless membahas istilah emik dan etik dalam kerangka model folk dan model analisis. Model folk adalah representasi stereotipikal, normatif, dan tidak kritis dari realitas yang dimiliki bersama oleh komunitas suatu kebudayaan. Sementara model analisis adalah representasi profesional, eksplanatoris, dan komprehensif dari realitas yang diakui oleh komunitas ilmiah. ${ }^{12}$ Emik dan etik tidak ada kaitannya dengan ontologi. Maka, suatu kejadian, situasi, hubungan dan fakta, tidak pernah terkait dengan emik maupun etik. Persoalan tersebut termasuk dunia empiris semata-mata sebagai kejadian dan entitas praksis. Suatu deskripsi, analisis, eksplanasi, atau klaim tertentu terhadap pengetahuan dikategorikan sebagai emik atau etik harus didasarkan pada

12. Brian Morris, Antropologi Agama, Kritik Teori-teori Agama Kontemporer (Yogyakarta: AKGroup, 2003) Cet. I, hlm. 78. Bandingkan dengan Bustanuddin Agus, Agama dalam Kehidupan Manusia, Pengantar Antropologi Agama (Jakarta: Rajawali Grafindo Persada, 2006), h. 91 
dasar-dasar epistemologis. Dalam perspektif ini, Marvin Haris membedakan terma emik dan etik atas dasar epistemologi, yaitu kerja emik mencapai tingkat tertinggi tatkala mengangkat informan yang diteliti dan analisis pengamat. Pengujian atas analisis emik adalah kemampuannya untuk menghasilkan pernyataan-pernyataan yang dapat diterima oleh objek yang diteliti secara riil, bermakna, dan aktual. Pada sisi lain, kerja etik mencapai tingkat tertinggi, manakala mengangkat pelbagai kategori dan konsep yang digunakan dengan mengacu pada landasan objektivitas. Pada kenyataannya, deskripsi dan eksplanasi antropologi dinamakan etik jika memenuhi hal-hal sebagai berikut:

1. Deskripsi harus bermakna sesuai dengan komunitasluas pengamat ilmiah.

2. Deskripsi harus divalidasi oleh pengamat secara independen

3. Deskripsi harus memenuhi persyaratan berupa aturan-aturan dalam memperoleh pengetahuan dan bukti ilmiah.

4. Deskripsi harus dapat diterapkan dalam tataran lintas budaya. Memang, sebagian antropolog, mementingkan eksplanasi yang valid dan dapat dipercaya dalam upaya merealisasikan etik.

\section{Perspektif Baru}

Dengan mengutip pendapat Junker dan Emmas, Kim Knott membagi konsepsi peran pengembangan interkoneksi sosial keagamaan dalam empat elemen; partisipan, peneliti sebagai partisipan, partisipan sebagai peneliti dan peneliti murni. ${ }^{13}$ Menurut kedua sosiolog tersebut, dengan landasan perspektif insider dan outsider, mereka diplot dalam sebuah kontinum sebagai berikut: jika dibuat diagram untuk menggambarkan peran mereka yang terlibat dalam penelitian keagamaan, maka akan dapat dilihat sejumlah hasil yang mungkin timbul, di antaranya adalah kutub berlawanan yang diikuti oleh dua posisi di pertengahan, di salah satu sisinya ia terlibat dalam kegiatan

13. Knott, Kim, Insider/Outsider Perspectives, dalam The Routledge Companion to the Study of Religion, Edited by John R. Hinnells (London: Routledge Taylor and Fancis Group, 2005), h. 176 
keagamaan sebagai partisipan dan di sisi lainnya ia mampu berinteraksi dengan penganut agama lain. Meski terkadang memunculkan sikap kritis, namun tak jarang masih terkooptasi oleh posisi insidernya.

\section{a. Partisipan Murni ( Complete Participant)}

Knott mengemukakan contoh, Fatima Mernissi sebagai gambaran sosok partisipan murni, terutama gagasannya ketika menulis An Historical and Theological Enquiry (1991) tentang perempuan dalam Islam. Sebagai seorang sosiolog feminis muslim, ia hampir tidak punya pilihan yang jelas. Mernissi sendiri mengutip sebuah kasus di mana ia dikecam oleh editor jurnal Islam, sebagai pendusta dan sosok yang tidak merepresentasikan tradisi Islam. Dia tentu bukan pemimpin Islam ataupun seorang teolog yang mempunyai otoritas, tetapi sebagai salah satu penulis muslim yang bermaksud mendeskripsikan esensi ajaran Islam, dengan mengeksplorasi khazanah keislaman untuk memahami hak-hak perempuan. Dalam kata pengantar bukunya, Mernissi yang dikenal sebagai pegiat feminisme yang banyak mengkritisi sejumlah hadis misoginis, ia menulis: "Sebagai wanita muslimah kita harus mampu memasuki dunia modern dengan bangga dan kepala tegak, gunamengembalikan harkat, demokrasi, dan hak asasi manusia. Dan untuk berpartisipasi penuh dalam urusan politik dan sosial, kita harus mampu menepikan nilai-nilai Barat, dan mengambil yang benar-benar dari tradisi Islam."14 Mernissi adalah prototipe sebuah emik, meski dinilai oleh banyak kalangan sebagai sosok yang kurang kritis. Alih-alih menggunakan parameter pendekatan studi agama atau sosiologi, ia hanya menggunakan pengalaman pribadi dengan bahasa Islam, khususnya, sentralitas konsep jilbab untuk memahami kebudayaan Islam yang eksklusif dan meyoroti posisi wanita dalam kungkungan tradisi domestik. Walaupun bukunya tidak diarahkan secara eksplisit untuk komunitas non-Muslim, Mernissi jelas menyadari adanya kritik Barat yang dominan, dan

14. Fatima Mernissi, Women and Islam: An Historical and Theological Inquiry, (Oxford: Blackwell, 1987), hlm. iii

Volume 24 Nomor 2 September 2013 
cenderung melihat Islam sebagai tidak demokratis dan menindas perempuan.

\section{b. Partisipan sebagai Peneliti (Participant as Observer)}

Dari tataran emik yang berlandaskan konsep pengalaman dekat menuju tataran etik, di mana bahasa ilmu sosial digunakan untuk menjelaskan aspek psikologis dan perilaku keyakinan agama. Pada saat mereka melakukan studi agama, maka yang dimunculkan adalah prinsip-prinsip kunci penelitian ilmiah sosial; objektivitas, netralitas, dan mutual konsultasi untuk membuktikan kebenaran hasil dari generalisasi mereka. Banyak sosiolog dan psikolog yang menggunakan pendekatan kuantitatif, misalnya, dengan mengembangkan dan mengelola sebuah kuisioner. ${ }^{15}$ Festinger memutuskan bahwa pendekatan semacam itu tidak dapat digunakan untuk mengkaji perilaku keberagamaan seseorang. Pada kenyataannya, apa yang mereka lakukan adalah menunggu tanda-tanda dari kegiatan kelompok keberagamaan, dan kemudian mengamati perilaku komunitasnya dari dalam. Mereka mengadopsi peran insider, untuk observasi sebagai pencari realitas tak langsung, sehingga akan didapat hasil yang lebih akurat. Dengan demikian, mereka menyadari adanya kebutuhan untuk memenuhi kondisi sosial, meskipun mereka menemukan diri mereka berangkat dari 'ortodoksi' ilmu sosial dalam beberapa hal, khususnya ketika tidak mampu tampil sebagai subjek anggota kelompok dengan menggunakan alat ukur yang standar.

Penggunaan beberapa istilah internal, semisal persoalan yang bersifat rahasia, stigmatisasi, anasir detektif peneliti, justru mempertajam distingsi antara pengamat outsider (dalam kontrol, tak terlihat, menyelidiki), dan insider sebagai objek yang diamati (pasif, sangat terlihat, terkena penyelidikan secara rinci). Hal ini, akan menaikkan suhu pembeda dan isu superioritas dalam penelitian ilmiah dan presentasi komunitas suatu agama. Dapat dikatakan, kasus ini gagal untuk melakukan penelitian secara berimbang dan objektif, karena peran peneliti dan

15. M. Atho' Mudzhar, Pendekatan Studi Islam dalam Teori dan Praktek, (Yogyakarta: Pustaka Pelajar, 2004).hlm. 11 
tuntutan penelitian yang diperlukan untuk mengkompromikan posisi mereka sebagai outsider demikian kuat. Meski, terbukti betapa sulitnya bagi peneliti untuk tidak terlibat dan tidak memihak ketika melakukan penelitian pada subjek agama apapun.

\section{c. Peneliti sebagai Partisipan (Observer os Paricipant)}

Sejak awal, Eileen Barker menolak melakukan penelitian tentang gereja Unifikasi baik secara praktis maupun etis, disebabkan dia bukan seorang Moonie (non sektarian). Dan tidak mau berpura-pura sebagai penganut salah satu sekte. Menurutnya, dalam menyelidiki Moonies, ia harus mengidentifikasi, membaur dan masuk menjadi penganut Moonies. Dan untuk kontekstualisasi ilmu-ilmu sosial, ia memiliki banyak kesamaan dengan pendekatan empati yang sering dipakai oleh peneliti fenomenologi agama sebelumnya semacam Kristensen, van der Leeuw dan Ninian Smart. Bahkan, Smart menggunakan metode agnostisisme, yang mengisyaratkan perlunya netralitas dan keluar dari truth claim dalam penelitian agama. ${ }^{16}$ Metode tersebut diidentifikasi oleh Smart - dan dilanjutkan oleh Barker ini mendominasi studi agama pada era 1970-an. Menurutnya, cara tersebut untuk mendekatkan adanya gap dikotomi antara insider-outsider, menjadi dua sisi yang integral dalam perspektif sehingga menjadi netral. Netralitas yang diinginkan, dalam arti tidak mudah terkooptasi untuk mendukung kepentingan tertentu yang bersifat empiris pragmatis. Senada dengan Smart, Cornelius Tiele memberikan polarisasi, meski masih rancu dan cenderung debatable dalam Elements of the Science of Religion (1897). Ia membedakan antara private religious subjectivity of individual (keberagamaan individu yang subjektif) dengan outward impartiality as a scholar of religion (peneliti kajian agama yang netral), sebagai instrumen mendasar untuk studi agama menuju pada hasil yang objektif. Meski dua tipologi itu memberi penegasan karakter, namun justifikasi dari keduanya yang masih memicu kontroversi, seakan ia telah menjustifikasi bahwa insider

16. Raymond Firth, An Anthropological Approach to the Study of Religion, dalam The Insider/Outsider Problem in the Study of Religion: a Reader, ed Russell T. McCutcheon, h. 64 
cenderung melihat persoalan keberagamaan secara subjektif, sedangkan peneliti outsider memandangnya secara objektif impartial.

\section{d. Peneliti Murni (Complte Observer)}

Kim Knott memberi ilustrasi, bagaimana seorang peneliti yang mencoba membedakan antara proses kompartementalisasi dan elaborasi nilai. Adalah seorang Samuel Hielman yang merasa tidak dapat mengatasi jarak; tidak dapat melarikan diri dari penghalang biografi, yang tercermin dalam penggunaan pengalamannya baik yang dekat maupun jauh. Ia juga tidak dapat menghindar untuk menggunakan istilah Ibrani, tetapi dia juga sering menggunakan bahasa studi agama dan ilmu-ilmu sosial guna menggeser perspektifnya. Berulang kali, ia menggunakan istilah-istilah seperti tradisi, budaya, liturgi dan teks suci, dari pada istilah dari Yahudi Ortodoks. ${ }^{17}$

Pengalaman keberagamaan Heilman memang subjektif. Namun, melampaui deskripsi pengalaman partisipan yang menggambarkan perannya sebagai sosiolog modernis Yahudi Ortodoks. Dia menyarankan bahwa proses observasi - orang lain dan diri sendiri - mampu membuat pemisahan. Ia juga berulang kali mencoba mengurai adanya perbatasan, hambatan, sekatsekat primordial yang menjadi persoalan krusial dalam dirinya. Dan itu bisa dibaca dalam otobiografinya, The Gate Behind the Wall. Dalam buku tersebut, ia menggambarkan kondisi dirinya sebagai seorang yang menghadapi ambiguitas dalam keberagamaan, yang harus terelaborasi dan terintegrasi dalam satu entitas yang sama, sehingga ia sulit untuk keluar dari tarikan kooptasi kedua sisi tersebut. Heilman menegaskan, bahwa ia telah berulang kali berusaha menutup batas antara dua dunia tersebut dan menemukan cara untuk membuat dirinya utuh dan terbebas dari religious split personality. Ia meneliti keberagamaan masyarakatnya di dalam sinagog. Namun, ia tetap berambisi untuk terlibat dalam lernen - istilah Yiddish untuk praktik Ortodoks Yahudi yang menafsirkan teks suci. Dari posisinya sebagai peneliti ini ia menggunakan metode spasial

17. Knott, Kim, dalam The Routledge Companion to the Study of Religion, Ibid, h. 179 
dengan memasuki wilayah tradisi keagamaan esoteris. Itu sebabnya, mengapa ia sering menggunakan istilah-istilah non Yahudi. Heilman menulis tentang ketegangan yang belum terselesaikan antara dua dunianya baik sebagai seorang Yahudi dan kapasitasnya sebagai sosiolog peneliti. Sedangkan Pearson menegaskan bahwa, apapun kesulitannya harus disikapi secara reflektif rasional. ${ }^{18}$ Collins juga menekankan, bahwa perbedaan antara insider-outsider menjadi tidak relevan ketika kita mengakui bahwa semua orang yang berpartisipasi, apakah beriman atau tidak, memberikan kontribusi pada pembangunan kemitraan secara sama. Sedangkan adanya dikotomi antara insider-outsider merupakan konsekuensi yang tidak kondusif untuk berpikir progresif. Pandangan ini serupa dengan yang diungkapkan oleh Mandair.

Mandair sendiri tidak sekadar mendeskripsikan, namun mengurai persoalan krusial ini berdasarkan pada klausa kasuistik. Dalam penjelasannya, seorang peneliti perlu mengusung jargon netralitas, imparsialitas, objektivitas, dan reduksionisme. ${ }^{19}$ Menurutnya, baik insider maupun outsider dalam melakukan kajian ilmiah selalu mengartikulasikan posisi mereka dalam istilah-istilah tersebut. Baik Collins dan Mandair, keduanya mengundang kita untuk menggunakan pendekatan negosiatif, dengan sedikit penekanan yang berbeda. Collins menawarkan wacana modernis dengan meninggalkan pandangan dikotomis insider-outsider untuk meraih hasil yang lebih dinamis, di mana setiap orang adalah partisipan aktif dalam merumuskan narasi tentang agama. Mandair lebih menikmati studi agama tentang bentuk penemuan diri. Pada umumnya, memang ilmuwan menyoroti persoalan subjektivitas dan objektivitas, perspektif emik dan etik, serta implikasi epistemologis dan metodologis tentang studi agama. Mereka mencoba mengkomparasikan antara iman dan dunia, sakral dan profan, faith dan tradition atau antara transendentally oriented

18. Robert W. Crapps, Perkembangan Kepribadian dan Keagamaan. terj. Agus M. Hardjana. (Yogyakarta: Kanisius, 1994), hlm. 43

19. Mandair, Arvind Pal Singh, Thinking differently about religion and history, in Chistopher Shackle, Sikh Religion, Culture and Ethnicity, (Curzon: Ritzmon, 2001), hlm. 47-48 
dan historical aspect, antara teologi dan studi agama. ${ }^{20}$ Memang, secara raison d'être banyak kiat dan pelbagai upaya untuk merekonstruksi arah religious studies. Pendekatan fenomenologis misalnya, ternyata masih belum mampu menemukan hakikat keberagamaan manusia yang sesungguhnya, sehingga perlu ditindaklanjuti melalui pendekatan alternatif filosofis kritis terhadap realitas keberagamaan yang berpijak pada aspek historis kultural secara menyeluruh. Apakah hal ini menunjukkan adanya perspektif baru bahwa masalah insider dan outsider, merupakan elemen penting dalam menyikapi keberagamaan saat ini guna memahami teori dan metode studi agama kontemporer?. Menuju Objektivitas Metodologi Studi Agama Persoalan yang sangat krusial dan dilematis dalam studi agama, adalah bagaimana seorang peneliti mampu menjaga objektivitas dan netralitas dalam melakukan kajian agama, baik sebagai insider maupun outsider. Konsep yang ditawarkan oleh Kim Knott adalah dengan pendekatan rapprochment, sebuah metode yang bisa kita lihat dalam hubungan skema triadik berikut : Subjektif (Firstness) Objektif Inter-Subjektif (Secondness) (Thirdness) Pendekatan rapprochment merupakan upaya solutif intersubjektif guna memposisikan peneliti pada margin of appreciation sebagai tapal batas (border line) antara insideroutsider.

Tawaran Kim Knott, yang diadopsi dari Richard J. Bernstein di atas menawarkan alternatif pendekatan dalam studi agama. Ia, menempatkan ketiga unsur di atas sebagai tautan reflektif sirkuler yang saling mengisi, dan bukan merupakan eksistensi yang berdiri sendiri, apalagi sebagai hubungan subordinat. Spirit yang ingin dimunculkan dalam konteks studi agama, adalah adanya titik temu dan bukan pembauran apalagi peleburan antar ajaran agama. Dalam aspek inter-subjektif itulah Kim Knott menyebut rapprochment sebagai instrumen dialogis akomodatif. Meski demikian, tetap saja menyisakan persoalan pelik dalam mengurai jelaga objektivitas. Sebagaimana dapat disimak dalam pandangan Muhammad Abdul Rauf, bahwa cara pandang subjektif sering membawa seseorang untuk memilih

${ }^{20}$. Mandair, Ibid, hlm. 64 
cara beragama dengan truth-claim, sebagai konsekuensi adanya keimanan. Rauf mencoba untuk mengelaborasi batasan outsider dalam bingkai metodologi kritisisme objektif. ${ }^{21}$ Dalam konteks Islam, kajian outsider berkaitan erat dengan pengalaman Barat dan sarjana Muslim sendiri dalam menafsirkan dan memahami Islam. Insider adalah para pengkaji Islam dari kalangan muslim. Sementara outsider adalah sebutan untuk para pengkaji nonMuslim yang mempelajari Islam dan menafsirkannya dalam pelbagai analisis dan pembacaan dengan metodologi tertentu. Bahkan, ia menegaskan, bahwa tema outsider tak hanya sebatas orang luar, namun termasuk insider yang melakukan kontrol sosial atau otokritik terhadap agamanya (ijtihadi-naqdi). Yang menjadi persoalan adalah apakah para pengkaji Islam dari outsider benar-benar objektif, dapat dipertanggungjawabkan, dan memiliki validitas ilmiah dilihat dari optik insider ?. Jika mereka mengkaji Islam atas dorongan kepentingan kolonial guna melestarikan hegemoni politik dan ekonomi atas daerah taklukannya, ia menolak hasil kajian outsider. Itu sebabnya Rauf menegaskan, bahwa studi Islam dalam optik outsider sering, dan dipenuhi oleh pelbagai motif dan kepentingan. Bahkan, ia mengingatkan, dalam membaca karya para outsider tentang Islam harus dilakukan dengan kritis dan penuh hati-hati. Apalagi bila yang dikaji adalah teks-teks suci yang untuk dapat memahaminnya diperlukan keyakinan, karena hal ini tidak dimiliki oleh para outsider. ${ }^{22}$

\section{Sistematika Kim Knott}

Penulisan Kim Knott diawali dengan pembukaan singkat mengenai problem-problem akademik yang dihadapinya. Lalu melanjutkan dengan masalah insider dan outsider untuk mencari objektifitas dalam sebuah penelitian. Yang mana selama ini masih ditemukan subjektifitas dalam berbagai macam penelitian.

21. Muhammad Abdul Rauf, Outsiders Interpretation of Islam, dalam Approaches to Islam in Religious Studies edited by Richard C. Martin, (Oxford: Oneworld Publications, 2001), hlm. 185

22. Muhammad Abdul Rauf, dalam Richard C. Martin, Perdekatan Terhadap Islam dalam Studi Agama, terjemahan Zakiyuddin Baidhowy, (Yogyakarta:UIN Sunan Kalijaga Press, 2010), hlm. 198 
Dia memberi tawaran baru dalam penelitian yaitu menempatkan 4 macam: partisipan murni, peneliti murni, peneliti sebagai partisipan, partisipan sebagai peneliti. Pada proses selanjutnya untuk membedahnya denganmenggunakan pendekatan spasial.

\section{Kesimpulan}

Melihat dari beberapa pembahasan diatas, maka Kim Knott memberikan hasil sebagai kesimpulan tentang Insider/Outsider Perspective In Religions And Islamic Studies antara lain sebagai berikut:

1. Kim Knott memberikan beberapa kontribusi terhadap pengetahuan (knowledge) antara lain: Pertama, memberikan sumbangan mengenai pemetaan insider dan outsider dalam studi agama. Kedua, memberikan sumbangan pemikiran yang berkaitan dengan pendekatan dalam penelitian studi agama. Dengan pendekatan spasial Kim Knott berusaha membedah masalah seputar agama. Namun, apabila kita kaji kembali tawaran Kim Knott ini tidak hanya bisa untuk mengkaji studi agama saja, lebih dari itu, bisa masuk pada wilayah kelimuan lain.

2. Kim Knott membagi konsepsi peran pemberdayaan interkoneksi sosial keagamaan dalam empat macam, yaitu : partisipan murni (Complete Participant), peneliti sebagai partisipan (Observer as Participant), partisipan sebagai peneliti (Participant as Observer) dan peneliti murni (Complete Observer).

3. Insider/outsider dalam studi agama, yaitu Pertama, belief, yang berupa tatanan sosial yang dipegang secara absolut, dan dipadu oleh tatanan kekuatan moral. Kedua, habit of mind, tradisi yang turun temurun dan telah mengkristal menjadi kebiasaan dalam pelbagai aspek kehidupan. Ketiga, doubt mempertanyakan tentang apa yang selama ini dianggap menjadi mainstream pemikiran untuk memperoleh keyakinan. Keempat, Inquiry (penelitian), namun ia menegaskan bahwa yang dicari adalah meaning (nilai) bukan truth (kebenaran), yang merupakan teori pemaknaan pragmatis namun operatif. Kelima, the logic of theory, sebagai landasan aplikasi kajian. 
Insider/Outsider Perspective ... Oleh : Untung Khoiruddin

Volume 24 Nomor 2 September 2013 


\section{Daftar Pustaka}

Abdullah, M. Amin, "Relevansi Studi Agama-Agama dalam Milenium Ketiga" dalam Amin Abdullah dkk., Mencari Islam (Studi Islam dengan Berbagai Pendekatan), (Yogyakarta: Tiara Wacana, 2000).

Adams, Charles J., “Islamic Religious Tradition” dalam Leonard Binder (Ed.) The Study of The Middle East : Research and Scholarship in the Humanities and the Social Science, (Canada: John Wiley and Sonc, Inc, 1976).

Brian Morris, Antropologi Agama, Kritik Teori-teori Agama Kontemporer (terjemahan Imam Khoiri), (Yogyakarya: Ak Group, 2003), Cet. I.

Brian Morris, Antropologi Agama, Kritik Teori-teori Agama Kontemporer (Yogyakarta: AKGroup, 2003) Cet. I. Bandingkan dengan Bustanuddin Agus, Agama dalam Kehidupan Manusia, Pengantar Antropologi Agama (Jakarta: Rajawali Grafindo Persada, 2006)

Fatima Mernissi, Women and Islam: An Historical and Theological Inquiry, (Oxford: Blackwell, 1987).

Hasan Hanafi, Oksidentalisme: Sikap Kita Terhadap Tradisi Barat, terj. (Jakarta: Paramadina, 2000).

Josef Van Ess, The Logical Structure of Islamic Theology, dalam An Anthology of Islamic Studies, edited by Issa J. Boullata, (Canada: McGill Indonesia IAIN Development Project, 1992).

Knott, Kim, The Location of Religion, a Spatial Analysis, (UK London: Equinox Publishing, 2005), First Edition

------------, Insider/Outsider Perspectives, dalam The Routledge Companion to the Study of Religion, Edited by John R. Hinnells (London: Routledge Taylor and Fancis Group, 2005).

Religion. 
M. Atho' Mudzhar, Pendekatan Studi Islam dalam Teori dan Praktek, (Yogyakarta: Pustaka Pelajar, 2004).

Mandair, Arvind Pal Singh, Thinking differently about religion and history, in Chistopher Shackle, Sikh Religion, Culture and Ethnicity, (Curzon: Ritzmon, 2001).

Milton K. Munitz, Contemporary Analytic Philosophy, (New York: Macmillan Publishing Co Inc, 1976).

Muhammad Abdul Rauf, Outsiders Interpretation of Islam, dalam Approaches to Islam in Religious Studies edited by Richard C. Martin, (Oxford: Oneworld Publications, 2001).

Muhammad Abdul Rauf, dalam Richard C. Martin, Perdekatan Terhadap Islam dalam Studi Agama, terjemahan Zakiyuddin Baidhowy, (Yogyakarta:UIN Sunan Kalijaga Press, 2010).

Sean McLoughlin, Migration, Diaspora and Transnationalism: Transformations of Religion and Culture in a Globalising Age dalam The Routledge Companion to the Study of Religion, Edited by John R. Hinnells (London: Routledge Taylor and Fancis Group, 2005).

Shiddiqi, Nourouzzaman, "Sejarah: Pisau Bedah Ilmu Keislaman" dalam Taufik Abdullah (Ed.), Metodologi Penelitian Agama: Sebuah Pengantar, (Yogyakarta: Tiara Wacana, 1991).

Kenneth L. Pike, Etic and Emic Standpoints for the Descpription of Behavior dalam Russell T. McCutchceon, The Insider-Outsider Problem in the Study of Religion, (London: Cassel, 1999), First Edition.

Raymond Firth, An Anthropological Approach to the Study of Religion, dalam The Insider/Outsider Problem in the Study of Religion: a Reader, ed Russell T. McCutcheon.

Robert W. Crapps, Perkembangan Kepribadian dan Keagamaan. terj. Agus M. Hardjana. (Yogyakarta: Kanisius, 1994). 
